\title{
THE FUTURE OF OCCUPIERS LIABILITY TO TRESPASSERS IN CANADA
}

\section{DAVID WILKINS*}

Concern with an occupiers duty to trespassers has recently developed into a major legal controversy in the Courts of England. The English Occupiers Liability Act ${ }^{1}$ has been hailed as an important step in the rationalization of the rigidities of the common law in this area. This Act imposes a general duty of care within the limits of the foreseeability test upon the occupier with respect to all his lawful visitors. Unfortunately the legislators did not believe similar reform was necessary in the category of trespassers. It should not be surprising that the same policy considerations which have produced legislative reform in the categories of invitees and licensees are challenging the common law treatment of the third category, that of trespassers.

The duty owed by an occupier to a trespasser under the common law is one of long standing. The presently accepted formulation has been clearly laid down by Lord Hailsham in Addie v. Dumbreck. ${ }^{2}$ In order to render the occupier liable;

There must be some act done with the deliberate intention of doing harm to the trespasser, or at least, some act done with reckless disregard of the presence of the trespasser. ${ }^{8}$

That this was the full extent of the occupiers duty to a trespasser was accepted without challenge until recently. This rule has been applied in a multitude of cases in England, Canada and the Australasian jurisdictions. The basis of the rule is that a man is entitled to use his property as he pleases and is not obliged to protect those who enter upon it without his permission. Simply stated, a trespasser must travel on another's land at his own risk.

However, this simple rule has received a complicated application by the Courts. The harshness of the rule in a particular case, especially one involving an innocent child who may have been killed or seriously injured during his trespass, has produced some fictional modifications. To avoid the affects of the rule the Courts have on numerous occasions implied, or rather imputed, a license for the Plaintiff's presence on the land. If the occupier fails to take active steps to prevent a trespass once he becomes aware of it a Court may infer a license. This places the trespasser in the category of licensee, thereby giving him the greater protection owing to persons falling within that category. But the application of this fiction has been confined by some judgments. Lord Parker expressed the limits of this doctrine in Edwards v. The Railway Executive.

There must . . . be such assent to the user relied upon as amounts to a license to use the premises... I do not accept the theory that every possible step

- L. David Wilkin, B.A., LL.B., of the 1966 graduating class.

1 (Imp.) 5 \& 6 Eliz. II, C. 31.

2 1929 [A.C.] 358. son, 1936 [S.C.R.] 200; Haines v. Brewster, [1938] 2 W. W. R. 285; Dean v. Edmonton (City) (1965), 51 W. W. R. (N.S.) 539 .

4 Commissioners for Railways v. Cardy (1960), 104 C.L.R. 274, 286, per Dixon, C. J.; Videan v. British Transport Commission [1963] 3 W. L. R. 374, 380, per Denning, i. J.

[1952] A.C. 737, 743-44. 
to keep out intruders must be taken, and if it is not, a license may be inferred. Whether that result can be inferred or not must, of course, be a question of degree, but in my view a court is not justified in lightly inferring it.

Viscount Dunedin giving judgment in Addie v. Dumbreck stated:

$\ldots$ it is permission that must be proved, not tolerance, though tolerance in some circumstances may be so pronounced as to lead to the conclusion that it was really tantamount to permission. ${ }^{6}$

The existence of an implied license is a question of fact. ${ }^{7}$ The onus lies with the plaintiff to show that the occupier was aware or should have been aware of the trespass and did nothing to prevent it. In some circumstances the courts have occasionally gone to some lengths to impute such a license, giving an injured trespasser a remedy for negligence where he would otherwise have had none. However, the courts have generally been very reluctant to imply a license where the occupier has taken steps to prevent a trespass, even though they have proved ineffective. They have consistently refused to require an occupier to fence his land or post guards to warn trespassers. ${ }^{8}$

The doctrine of "implied license" seems to receive its broadest application in cases involving child trespassers. The existence of an allurement -an object of fascination to children which is nevertheless dangerousis one circumstance to be considered in determining the existence of an implied license. ${ }^{0}$ Under allurement principles, an occupier might be deemed to know that children would attempt to gain access to a fascinating object situate upon his property. Once the child has been elevated to the status of a lawful visitor, the allurement may be treated as a trap, rendering the occupier liable for the injuries to the child which result from his interference with the allurement. Moreover, the allurement principle may permit recovery where the child has been injured while exceeding the limits of his invitation or license. ${ }^{10}$

It must be noted that the allurement doctrine in English jurisdictions, unlike the American position, ${ }^{11}$ does not create a separate duty owing to child trespassers. ${ }^{12}$ The existence of an allurement is irrelevant if the child has been classified as a trespasser. ${ }^{13}$ The existence of an object of fascination may be of assistance to a child trespasser only in the sense that it may help him to persuade the court to elevate his status from trespasser to licensee. In its practical effect, the doctrine of allurement may impose upon the occupier a more stringent obligation to ensure that the measures taken to prevent a trespass are effective enough to preclude the possible inference of a license. The doctrine of allurement in child trespasser cases has been strictly confined from another aspect. A child relying on the existence of an allurement must be old enough to be fascinated by it ${ }^{14}$ while immature enough to be unable to appreciate the danger it creates. ${ }^{10}$

6 Ante, n. 2, at 373; See also Riopelle v. Desjardins [1950] O.R. 93.

7 Grand Trunk Raitway v. Barnett, ante, n. 3.

8 Haines v. Brewster, ante, n. 3, at 288; Popein v. Link Bros. Construction Ltd. (1963), 43 W. W. R. (N.S.) 123; Edwards v. Railway Executive, ante, n. 5.

o Midland Ratiway v. Cooke, [1909] A.C. 229; Latham v. Johnson, [1913] 1 K.B. 398, 416; Wallace v. Petit (1923), 55 O.L.R. 82.

10 Charlesworth on Negligence, 238 (2nd Ed.) citing Latham v. Johnson, ante, n. 9.

11 American Restatement of Torts, 2nd, para. 339.

12 Haines v. Brewster, ante, n. 3; East Crest Oil Ltd. v. The King, [1945] S.C.R. 191.

18 Hardy v. Central London Railway, [1920] 3 K.B. 459.

14 Jenkins v. Great Western Railway, [1912] 1 K.B. 525.

is McEwen v. C.N.R. (1962, 38 W.W.R. (N.S.) 76; Storms v. Winnipeg S.D. No. 1 (1963),

44 W.W.R. (N.S.) 44. 
It must also be noted that the protection of the rule in Addie v. Dumbreck has been restricted to the occupier and those for whom he is responsible. ${ }^{10}$ A contractor carrying out operations on the land of another is under a general duty of care to see that his activities do not injure on the land. He is not protected by a defence that the injured plaintiff was only a trespasser upon the land. Recent cases in the English Court of Appeal have refused to draw any distinction between the duty owed by a contractor carrying out operations on the land and the duty owed by an occupier carrying out similar operations. ${ }^{17}$

These distinctions are in reality fictional. ${ }^{18}$ The courts are looking to the extrinsic circumstances of the plaintiff's legal characterisation to determine the existence of a duty. Critics of this approach insist that while the legal character of the plaintiff is certainly relevant to the determination of the extent of the duty imposed upon the occupier, it should not be the sole criteria for determining the existence of that duty. It has been suggested that the law relating to trespassers is out of touch with the prevailing social attitudes. ${ }^{10}$ The belief that the duty of a land owner should be solely determined by the artificial legal status of his guest is not consistent with the general principles of negligence. Recent judicial pronouncements point out that there is no logical reason for exempting an occupier of land from the obligations owed by every man to his neighbor. ${ }^{20}$ In societies where the instance of innocent trespass, for example a straying child or an inquiring pedestrian, occurs with great frequency it may be that it is no longer a desirable social policy to allow an occupier complete freedom upon his land without regard for the welfare of these trespassing persons.

The English Court of Appeal has recently attempted to exert an influence toward the mitigation of the undesirable effects of the "categories approach" to occupier's liability. Since the passage of the Occupiers Liability $A c t^{21}$ the concern of the English courts has been confined to the area of trespassers. Lord Denning has suggested a distinction between the current operations which an occupier carries out on his land and the static condition of his land. ${ }^{22}$ The only obligation upon the occupier for the static condition of his land is that stated in Addie v. Dumbreck. But with regard to his activities on the land, the responsibility is greater. Commenting on the duty owed by contractors working on the land, Lord Denning suggested that the ordinary duty to take reasonable care, imposed by a test of foreseeability of harm, should apply equally to occupiers of land carrying out operations on their land.

In the ordinary way the duty to use reasonable care extends to all persons lawfully on the land but it does not extend to trespassers for the simple reason that he (the occupier) cannot ordinarily be expected to foresee the presence of a trespasser. But the circumstances may be such that he ought to foresee 16 A. C. Billing \& Sons Ltd. v.Riden, [1958] A.C. 240; Gallagher v. N. McDowell Ltd.,

17 Videan case, ante, n. 4, at 381, per Denning, L. J.; at 388, per Harman, L. J.

18 Commissioners for Railways v. Cardy ante, n. 4, at 282 per Dixon, C. J.

10 Morrison, Trespassers in the Wilderness, (1965), 38 Aust. L. J. 331; Munkman, Trespassers: An Out of Date Approach ( ), 114 L.J. 316; Harris, Some Trends in the Law of Occupiers Liability (1963), 41 Can. Bar. Rev. 401, 442.

20 Videan case, ante, $n .4$, at 392, per Pearson, $L$. J.

21 ante, n. 1.

22 Videan case, ante, n. 4, at 384, per Denning, L. J. 
even the presence of a trespasser; and then the duty extends to the trespasser also.23

Lord Denning confines the application of the Addie v. Dumbreck rule to the occupier's liability "as occupier" for the condition of his premises. But he further states that the existence of this duty does not exempt the occupier from the duty owing to his neighbor to conduct his activities with reasonable care. ${ }^{24}$

The suggestion that an occupier may be subject to an overriding duty of care owed to trespassers had earlier appeared in pronouncements of the High Court of Australia. ${ }^{25}$ Fullager, J. explained that the common law imposed a duty of care upon the occupier, as occupier, to protect his lawful visitors. But he also pointed out;

There is no special duty (owed to trespasser) but circumstances over and above the character of the visitor as trespasser may give rise to a general duty of care, with the result that an occupier is liable to the trespasser for negligence. ${ }^{26}$

Dixon, C. J. challenged the necessity of resorting to the categories and their accompanying fictions. He stated:

In principle, a duty of care should rest on a man to safeguard others from grave danger of serious harm, if knowingly he has created a danger or is responsible for its continued existence and is aware of the likelihood of others coming into proximity of the danger and has the means of preventing it or averting the danger, or of bringing it to their knowledge. ${ }^{27}$

In proposing this duty, the court made no distinction between the operations on land and its static condition. Pearson, L. J. also failed to see the logic in such a distinction in his judgment in the Videan case. ${ }^{28}$ He stated that such a distinction is confusing and quite unnecessary to the rationalization of the law. In his opinion if a trespasser must take the premises as he finds them, he should also be obliged to take the occupiers operations as he finds them. ${ }^{29}$ But he did agree with the other members of the court that some duty was owed to the foreseeable trespasser. In his opinion:

If ... the presence of the trespasser is known to, or reasonably to be anticipated by, the person concerned (whether he be the occupier or a servant or agent of the occupier, or his invitee or licensee, or a person coming into the land as of right), that person owes some duty of care to the trespasser because he must treat even a trespasser with common humanity, ${ }^{30}$

There are some who object to the use of the label "common humanity" as being non-definitive but the writer believes what Pearson, L. J. intended by the term was a duty of reasonable care within the general principles of negligence that common humanity has accepted. His suggestion might be more properly treated as an expression of the rationale for a duty rather than a definition of the limits of that duty.

It is submitted that Lord Denning's careful distinction is not acceptable. His attempt to distinguish current operations from the static condition of land is only a compromise between stare decisis and a desire to reform the law. In reality, he has produced another fiction. The test in

23 Id. at 382

24 Id. at 380 . This interpretation of the law was also suggested by Harris, ante, n. 19.

25 Cardy case, ante n. 4; Rich v. Commissioner for Railways, (1959), 101 C.L.R. 135 (N.S.W.)

20 Cardy case, ante, n. 4 , at 296

27 Id. at 286.

28 Videan case, ante, n. 4, at 393.

20 Ibid.

30 Id. at 394. 
Addie v. Dumbreck deals with the occupier's act done intentionally or with reckless disregard for the presence of trespassers. ${ }^{31}$ That this test should now be confined to the occupier's non-feasance does not appear a logical development. The results of Lord Denning's distinction may seem desirable but this modification of the law does not appear to have been applied in a Canadian jurisdiction. ${ }^{32}$

A recent decision of the Privy Council has added fuel to the controversy by re-asserting the traditional rule. On an appeal from the Australian High Court in Commissioners for Railways v. Quinlan, ${ }^{33}$ Viscount Radcliffe unequivocally stated that the occupier's duty as laid down in Addie v. Dumbreck was intended to be an exclusive and comprehensive definition of the duty imposed on an occupier. This judgment rejects any distinction between static conditions and current operations as being "not maintainable, either in principle or on authority". ${ }^{34}$ Commenting on the Australian court's proposition that there exists an overriding duty upon the occupier, apart from his characterization as occupier, Viscount Radcliffe stated:

It does not seem to them (their Lordships) that there is any room for any useful distinction between an occupier as such and an occupier in some other character or capacity. ${ }^{85}$

And further:

It does not alter a trespasser's description merely to christen him a neighbor. ${ }^{86}$

In the course of the judgment, the court rejected any possibility of creating a duty from the general principles laid down in Donoghue v. Stevenson. ${ }^{37}$ While offering his observations on the "accepted formulation of the occupier's duty to a trespasser", Viscount Radcliffe insisted that the rule expressed in Addie v. Dumbreck is not the old law but the law.:8 In arriving at this conclusion he seemingly overruled or distinguished all the recent attempts in the English and Australian courts to modify the law in this area.

The only scope for modification of the harshness of the rule in Addie v. Dumbreck which is left open by this decision is liberality in the interpretation of what constitutes an act done with reckless disregard of the presence of a trespasser. Viscount Radcliffe stated that the rule in Addie v. Dumbreck:

... may embrace an extensive and, it may be, an expanding interpretation of what is wanton or reckless conduct towards a trespasser in any given situation ... What the law does not admit, however, is that a trespasser, while incapable of being described otherwise than as a trespasser, should be elevated to the status of an ordinary member of the public, to whom, if rightfully present, the occupier owes duties of foresight and reasonable care. ${ }^{30}$

81 Id. at 380.

32 MacDonald and Lelgh, Law of Occupiers Liability and the Need for Reform in Canada. (1965), 16 U. Toronto L.J. 55, 73.

33 [1964] A.C. 1054, 1073-4.

34 Ibid.

35 Ibid.

36 Id. at 1084.

37 [1932] A.C. 562.

38 Quinlan case, ante, n. 33, at 1078.

89 Id at 1084 
He states the conclusions of the court at the end of the judgment.

(Their Lordships) ... think, with respect, that the situation would be less liable to be misunderstood if it were explained that the only trespasser to whom the occupier is accountable for his actions, even if dangerous, is one of whose presence he actually knows or one whose presence at the time of injury can fairly be described as extremely likely or very probable.40 40 Id. at 1086.

The reaction of this judgment by legal writers has been strong and varied. One Australian writer has surprisingly suggested that the judgment does not preclude the application of the test laid down by Dixon, C. J. in the Cardy case, even in Australia!"1 Another is critical of the role played by the Privy Council in the development of the law and suggests it would be erroneous to treat the decisions of the English Court of Appeal as having been overruled."2 In his article on the Quinlan case, ${ }^{43}$ Professor Goodhart suggests that the Privy Council was wrong in treating the rule in Addie v. Dumbreck as being the clearly established law. Furthermore, he added that even if the rule was clear, the law should be alterable to meet modern social needs. Another writer has attacked the attitude taken by the Privy Council as opposing desirable reform in this area of the law."4

This controversy has not been as volatile in Canadian jurisdictions. There have been few cases which have challenged the accepted formulation in Addie v. Dumbreck. ${ }^{45}$ At present the law in Canada remains fixed with the "categories approach" to occupier's liability. For Canadian jurisdictions, Viscount Radcliffe's judgment in the Quinlan case ${ }^{ \pm 0}$ accurately describes the state of the law. But we should not dismiss the views of leading judicial reformers in other parts of the Commonwealth without serious consideration. The social conditions which have produced the attempted reforms in English and Australian law also exist in Canada. There has been a growing trend in Canada, which is even more advanced in the United States, in support of a wider interpretation of accident liability. The basic guidelines for such a movement exist in the foreseeability test created in Donoghue v. Stevenson." In offering their proposals for the English Occupiers Liability Act ${ }^{ \pm 8}$ the Law Reform Committee felt it unnecessary to effect a change in the law relating to trespassers. ${ }^{49}$ As the Canadian Commissioners on Uniformity of Legislation consider the feasibility of statutory reform of Canadian law in this area, it is to be hoped that some provision will be proposed for placing the law relating to trespassers as well as lawful visitors on a rational basis, consistent with general principles of the law of negligence.

It is submitted that the creation of a general duty of care in this area will not place an onerous burden upon the occupier and need not necessarily create an undesirable encroachment of his proprietary rights. In fact, the extent of the duty may be minimal in the circumstances. The judgments of the English Court of Appeal and the Australian High Court

11 P. G. Hely (1965), 5 Syd. L. Rev. 175, 176

42 Munkman, ante, n. 19

43 Goodhart, Adult Trespasser (1964), 80 L. Q. Rev. 559.

44 Morrison, ante, $n$. 18, at 332 . J.A. (B.C.C.A.); Popein v. Link Bros. Construction Ltd. ante, n. 8, per McPherson, J. (Sask.).

4i Ante, n. 33

47 ante, n. 37 .

48 ante, n. 1 .

t9 McDonald and Leigh, ante, n. 32, at p. 73. 
have enumerated some factors which should be relevant to the determination of the extent of the duty existing in any particular circumstances. ${ }^{50}$ Because the test is based on foreseeable harm to the plaintiff, the occupier will not likely be required to take any more precautions than he formally was because, generally speaking, he will be unaware of the presence of the trespasser. However, it is submitted that an approach based on general principles of negligence will provide more scope for a court to do justice in a particular case without resort to the fictional devices which have formerly been implemented to offset the rigidity of the "categories approach." At the same time such a change will bring the law relating to occupier's liability into line with the generally accepted principles of negligence which exist to govern the relationships of men in other areas of human activity. 